\title{
VREDNOTENJE NARAVNIH IN DRUŽBENIH DEJA- VNIKOV ZA POTREBE SONARAVNEGA RAZVOJA S POMOČJO GEOGRAFSKIH INFORMACIJSKIH SISTEMOV
}

Rok Ciglič, univ. dipl. geog.

Geografski inštitut Antona Melika ZRC SAZU

Gosposka 13, SI-I000 Ljubljana

e-mail: rok.ciglic@zrc-sazu.si

Izvirni znanstveni članek

COBISS 1.01

\section{Izvleček}

Načrtovanje raznih dejavnosti v prostoru je zahtevno in odgovorno. Terja dobro poznavanje naravnih in družbenih razmer, poleg tega pa morajo biti rezultati v procesu načrtovanja podani čim bolj nazorno. V prispevku smo na primeru občine Kočevje skušali določiti najbolj primerne nepozidane površine za morebitno širjenje poselitve $\mathrm{z}$ vidika naravnih in družbenih dejavnikov. Pri tem smo uporabili metode geografskih informacijskih sistemov.

Ključne besede: regionalna geografija, geografski informacijski sistemi, poselitev, sonaravni razvoj, prostorsko planiranje, Kočevje

\section{EVALUATION OF NATURAL AND SOCIAL FACTORS FOR SUSTAINABLE DEVELOPMENT WITH THE HELP OF GEOGRA- PHICAL INFORMATION SYSTEMS}

\begin{abstract}
Planning the locations in areas with various types of land use is complicated and important work. It requires extensive knowledge of natural and social conditions and, also, the presentation of results in illustrative and understandable manner. This article defines the most suitable uninhabited areas for potential settlement in the Kočevje municipality with respect to natural and social factors. Geographical information systems were used for the analysis.
\end{abstract}

Key words: regional geography, geographical information systems, settlement, sustainable development, spatial planning, Kočevje 


\section{UVOD}

Pri prostorskem planiranju se soočamo z dilemo, kam v prostoru umestiti posamezno dejavnost. V prostoru se spreminjajo različni naravni in družbeni dejavniki (kamninska podlaga, relief, podnebje, rastje, raba tal, prometna infrastruktura idr.). Njihove kombinacije ustvarjajo različne tipe pokrajin, med katerimi ima vsaka svoje lastnosti. Te lahko na različne načine ovrednotimo, npr. z vidika ekosistemskih funkcij, primernosti za kmetijstvo, privlačnosti za turizem. Na drugi strani pa ima vsaka človekova dejavnost določene lokacijske zahteve, kot so npr. posebne naravne razmere, naselbinsko omrežje in drugo (Vrišer 1997).

Ker se torej $\mathrm{v}$ prostoru prepletajo različni dejavniki, ki ustvarjajo enovito podobo posameznih pokrajin, jih moramo pri načrtovanju dejavnosti ustrezno upoštevati, oziroma skušati vključiti čim več pomembnih. Njihovo zanemarjanje ne bi bilo v skladu z načeli sonaravnega razvoja, ki poudarjajo prilagajanje poselitve, pokrajinske rabe, gospodarstva in infrastrukture naravnogeografskim in družbenogeografskim značilnostim določenega geografskega območja (Plut 2002). Zato je bilo ocenjevanje zmogljivosti okolja in naravnih virov za materialno dejavnost človeštva ter nosilnosti okolja prilagojeno prostorsko razmeščanje prebivalstva in dejavnosti označeno kot izjemen metodološki in vsebinski izziv (Plut 2005). Zato je tudi v enem izmed temeljnih državnih prostorskih dokumentov, Strategiji prostorskega razvoja Slovenije (2004), v več ciljnih sklopih poudarjena racionalna raba ter podana priporočila, da mora biti razvoj prilagojen naravnim razmeram in rabi tal ter da mora biti za prostorski razvoj raznih dejavnosti zgrajena tudi ustrezna infrastruktura.

Tako imamo za posamezne dejavnosti bolj in manj primerne ali celo neprimerne lokacije. Pri tem se pojavi še prekrivanje interesov med dejavnostmi. Ustreznost prostora, ki naj bi odražala strokovno uskladitev med varovalnimi in razvojnimi interesi v prostoru, je bila kot rezultat soočenja primernosti in ranljivosti prostora opredeljena tudi že v nekaterih vsebinskih in metodoloških navodilih za izdelavo analiz strokovnih podlag za nekdanje planske akte (Černe 2002).

\section{I.I Načrtovanje poselitve}

Pri opredeljevanju primernosti se srečamo z velikim številom možnih kriterijev, med katerimi moramo najti najprimernejše. Med kriterije primernosti in omejitev spadajo med naravnimi pogoji za poselitev po Pogačniku (1992; 1999) raven hrupa, naklon, mikrorelief, klima, lega, stabilnost in nosilnost, območje podtalnice, območje virov pitne vode, mineralnih in zdravilnih vrelcev, območje izven obsega pogostih poplav, primernost kmetijskih zemljišč in kvaliteta gozda, čistost okolja in zraka, območje naravne dediščine in kakovostnih biotopov, nahajališča rudnin, bližina obal, rek, jezer, krajinski ambient, količina vode za gospodinjstva, sposobnost odvajanja odplak, seizmična aktivnost zemljišča, obstoječa degradacija naravnega okolja. Drugi kriteriji so še razvitost prometnega, energetskega in komunalnega omrežja z rezervati in obveznimi odmiki od tras infrastrukture, obstoječa raba površin, bližina oskrbnih središč ter delovnih mest, območja varstva kulturne dediščine, druga zavarovana območja (vojaški poligoni), najkvalitetnejši oblikovani urbani in vaški prostori, izvori emisij (tudi hrupa), območja izjemno onesnaženega okolja, lastništvo zemljišč, razne pravice in obremenitve na nepremičninah, veljavni prostorski dokumenti in družbeno mnenje. 


\section{I.2 Uporabnost metod geografskih informacijskih sistemov pri načrtovanju}

Če hočemo pri načrtovanju ta dejstva upoštevati, moramo preučiti ogromno podatkov. Pri velikih površinah z več dejavniki (podatkovnimi sloji) je raba geografskih informacijskih sistemov neizogibna, saj bi v nasprotnem primeru veliko dejavnikov ter velike količine enot (npr. rastrskih celic) preveč otežile in upočasnile raziskovalno delo.

V predstavljeni metodologiji imajo GIS-i pomembno vlogo in zato v naslednjem odstavku na kratko opisujemo postopek, ki je računska osnova za združevanje podatkovnih slojev na vseh ravneh metodologije vrednotenja naravnih in družbenih dejavnikov za potrebe prostorskega načrtovanja po načelih sonaravnega razvoja. Podrobnejša predstavitev metode je opisana v priročniku za program Idrisi (Eastman 2001), s katerim smo tudi opravili celotno analizo.

Pri iskanju rešitve $\mathrm{z}$ vidika več različnih dejavnikov (podatkovnih slojev) se srečamo $\mathrm{z}$ večkriterijskim vrednotenjem. Za reševanje takega problema sta med drugimi poznani tudi metodi Boolovo prekrivanje kart in obtežena linearna kombinacija (ang. weighted linear combination - WLC). Prva omogoča združevanje posameznih dejavnikov (binarnih podatkovnih slojev) z logičnimi operacijami. Med pogosto uporabljene sodita predvsem operaciji logičnih IN ter ALI, ki podata dve različni rešitvi - prikaz območij, kjer so ugodni prav vsi prisotni dejavniki, ali pa območij, kjer je prisoten vsaj en ugoden dejavnik. Preostala območja so v obeh primerih popolnoma neprimerna.

Metoda WLC omogoča obdelavo dejavnikov (imenovanih tudi faktorjev), ki imajo več kot le dve vrednosti. Take podatkovne sloje lahko, ob standardizaciji na enotno mersko lestvico, obtežimo ter seštejemo. Rezultat je tako podan z vmesnimi vrednostmi od vključno 'popolnoma neprimerno' do vključno 'popolnoma primerno'. Obe metodi se lahko dopolnjujeta. Rezultat Boolovega prekrivanja lahko služi kot sloj omejitev, kjer združimo vsa popolnoma neprimerna območja, npr. zavarovana območja, vodne površine in podobno. Ostale dejavnike $\mathrm{z}$ več vrednostmi, ki se zvezno spreminjajo v prostoru (nadmorska višina in podobno) združujemo z metodo WLC. Veliko pozornosti je treba nameniti tudi določanju uteži, katere določimo bolj ali manj subjektivno - po strokovni presoji, lahko tudi s pomočjo kvantitativnih metod. V programu Idrisi je za to namenjeno orodje WEIGHT (Eastman 2001).

\section{OSNOVNA METODOLOGIJA VREDNOTENJA NARAVNIH IN DRUŽBENIH DEJAVNIKOV IN NJENA UPORABA}

Nujnost upoštevanja naravnih in družbenih značilnosti poudarjajo razni pristopi. Na to še posebej opozarja metodologija študije ranljivosti okolja (ŠRO), ki prilagajanje okolja na spremembe zaradi človekovih posegov vidi kot 'ekološko tehtnico' s samočistilno, nevtralizacijsko in regeneracijsko sposobnostjo naravnega okolja na eni strani ter antropogene pritiske na drugi. S preučevanjem obeh strani lahko določimo ranljivost okolja in posameznih pokrajinotvornih sestavin ter predlagamo stopnjo varovanja oziroma še dovoljenega posega (Špes in sod. 2002). 
Ta dejstva so bila osnovno vodilo tudi pri izdelavi metode za ugotavljanje primernosti okolja za razvoj (umestitev) določene dejavnosti z vidika naravnih in družbenih dejavnikov na izbranem območju, ki jo predstavljamo $\mathrm{v}$ tem prispevku na primeru poselitve $\mathrm{v}$ občini Kočevje. Metoda ima podobne nazore, a se v marsičem razlikuje od ŠRO. V uporabljeni metodi ne uporabljamo pokrajinskoekoloških enot, temveč rastrske celice z lastnimi vrednostmi za vsak dejavnik. Vrednotenje podatkov je sicer potekalo delno tudi v smislu ekološke tehtnice, vendar smo se vrednotenja lotili na drugačen način. Ločeno smo vrednotili:

- primernost $\mathrm{z}$ vidika naravnih dejavnikov;

- primernost $z$ vidika rabe tal in

- primernost z vidika zgrajene infrastrukture.

Vrednotenje družbenogeografskih značilnosti smo torej razdelili na dva sklopa. Raba tal je bila vrednotena z vidika obremenjenosti okolja ter tudi z vidika njenega pomena za lokalno gospodarstvo. Vrednotenje infrastrukture je potekalo z vidika razvojnih potencialov; torej z namenom oceniti obstoječo opremljenost območja z infrastrukturnimi elementi, ki so nujni za poselitev.

Prostorskih podatkov je na voljo vse več in zato so takšne metode mogoče. Zaradi širokega razpona vključenih dejavnikov in osnovnega pristopa je metoda urejena v dve ravni. Na prvi ravni je razdeljena na tri zgoraj omenjene sklope, ki so podrobneje opisani v nadaljevanju. Na drugi ravni pa gre praktično le za združitev rezultatov posameznih sklopov, ki podaja sintezno karto (slika 1).

Pri vrednotenju primernosti $\mathrm{z}$ vidika naravnih dejavnikih se upošteva, kakšne so regeneracijske in nevtralizacijske sposobnosti območja ter kako primerno je območje za določeno dejavnost (v našem primeru poselitev). Izloči se območja popolnih omejitev (npr. poplavne površine), posamezne dejavnike pa se ovrednoti (npr. vrednotenje naklona glede na možnost pojava pobočnih procesov ob gradnji). Pri nekaterih dejavnikih regeneracijska sposobnost ni toliko pomembna, je pa dejavnik vseeno pomemben pri izbiri lokacije za poselitev. Takšen primer je npr. razporeditev prejete energije Sončevega obsevanja, saj naselja na bolj sončnih legah porabijo manj energije za ogrevanje. Vsi dejavniki morajo biti ovrednoteni na enotno mersko lestvico, v našem primeru od 0 do 5 ( 5 je najbolj primerno). Vrednotenje za območje občine Kočevje je bilo izvedeno s pomočjo strokovne literature $s$ posameznega področja. Enak način mora biti uporabljen tudi v preostalih dveh sklopih.

Pri vrednotenju rabe tal se upošteva, kako obremenjujoči so posamezni tipi rabe tal za okolje in hkrati, kako pomembni so za lokalno gospodarstvo. Za primer lahko vzamemo njivske površine, ki so sicer na obravnavanem območju najbolj intenzivne oblike kmetijstva (Rejec Brancelj 2001), a so hkrati pomemben vir pridelave krme za živinorejske obrate. Zato je bilo območje njiv označeno kot manj primerno za poselitev. Kot pomembna so bila ovrednotena tudi območja sadovnjakov, predvsem zaradi ohranjanja starih ekstenzivnih sadovnjakov. Razlog za ohranjanje kmetijskih obdelovalnih površin je tudi zaradi nevarnosti, da bi se morale kmetijske površine umakniti na manj rodovitna območja, kjer pa bi morali biti snovni in energijski vnosi za enak pridelek večji. Pomembna podatka sta lahko tudi delež površine posameznega tipa rabe tal ter pričakovano spreminjanje omenjenega deleža $\mathrm{V}$ prihodnosti (npr. širjenje gozdnih površin zaradi opuščanja kmetijstva). 
Pri vrednotenju tretjega sklopa oziroma zgrajene infrastrukture je v ospredju predvsem dostopnost oziroma možnost priključka nepozidanih območij na cestno omrežje, vodovod, električno omrežje, daljinsko ogrevanje in podobno. Tako so območja blizu takšni infrastrukturi ter hkrati izven njihovih varovalnih pasov označena kot najbolj primerna, primernost pa se z oddaljenostjo zmanjšuje. Pri oddaljenosti se upošteva tudi naklon, ki podaja informacijo o stopnji prehodnosti, in neprehodna območja (jezera in podobno).

Slika 1: Osnovna metodologija vrednotenja naravnih in družbenih dejavnikov za sonaravni razvoj izbrane dejavnosti

Figure 1: Basic methodology of evaluation of natural and social factors for sustainable development of specific land use

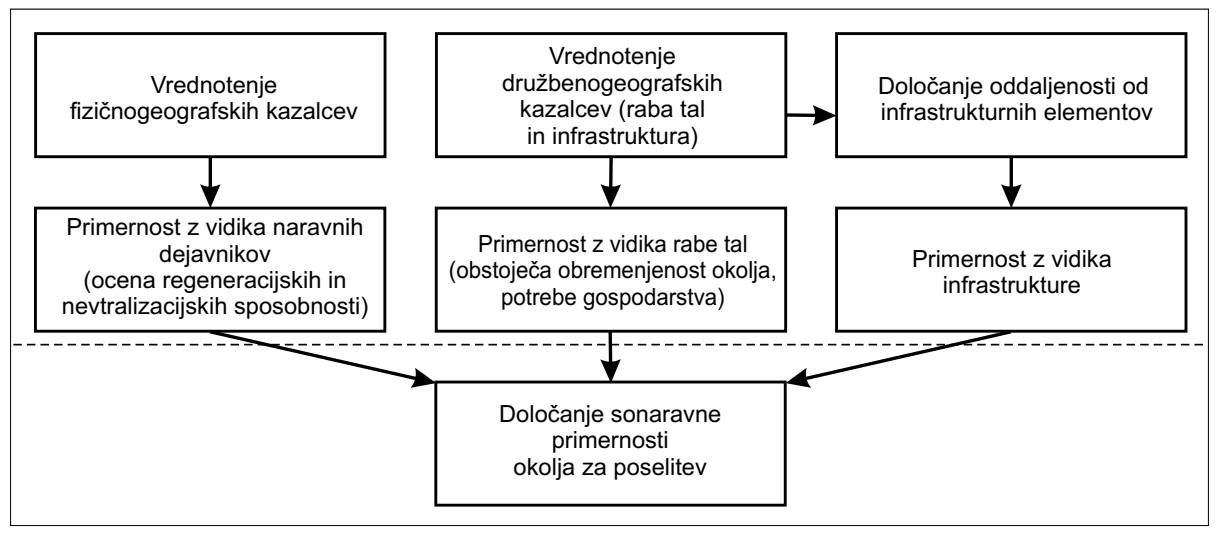

Vmesni koraki oziroma združevanje podatkovnih slojev poteka s pomočjo že opisanega postopka večkriterijskega vrednotenja. Tako so najprej na prvi ravni narejeni trije sintezni podatkovni sloji, nato pa jih na drugi ravni po enakem postopku združimo $\mathrm{v}$ en sam podatkovni sloj, ki prikazuje primernost območja za izbrano dejavnost.

\section{I Uporaba metode na primeru občine Kočevje}

Predstavljena metoda je bila uporabljena pri iskanju potencialnih prostih (nepozidanih) površin za poselitev na območju občine Kočevje. Obstoječa poselitev je trenutno izrazito dvodelna - koncentracija prebivalstva (90 \% od 16.292 prebivalcev) in dejavnosti na Kočevskem polju s središčem v mestu Kočevje na eni strani ter redka poselitev v obliki manjših naselij vzdolž glavnih prometnic s skupno $10 \%$ prebivalstva na drugi strani. Na območju izven Kočevskega polja je le nekaj naselij z več kot 100 prebivalci: Kočevska Reka, Novi Lazi, Štalcerji, Morava in Mozelj (medmrežje 3). Takšna poselitev je posledica naravnih razmer in dogodkov v preteklosti. Območje je bilo namreč po odselitvi kočevskih Nemcev in vojnem pustošenju sredi 20. stoletja skoraj neposeljeno. Ponovna naselitev je bila usmerjena predvsem na Kočevsko polje ter nekatera omenjena večja naselja. H koncentraciji poselitve je prispevala tudi ureditev varovanega območja okrog Gotenice in Kočevske Reke (medmrežje 2). 
V takih razmerah se poraja vprašanje, kje so najustreznejša območja za morebitno širjenje poselitve v prihodnosti, saj je znano, da je bila poselitev včasih bolj razpršena, danes pa je usmerjena h koncentraciji na Kočevskem polju. Torej: »Kakšen naj bo prihodnji razvoj?« S predstavljeno metodo lahko bolje odgovorimo na vprašanja o tem, kam naj se širijo naselja, katere opuščene vasi je smiselno obnoviti, kje razviti turistično naselje in podobno.

\section{Slika 2: Karta občine Kočevje}

Figure 2: Map of Kočevje municipality

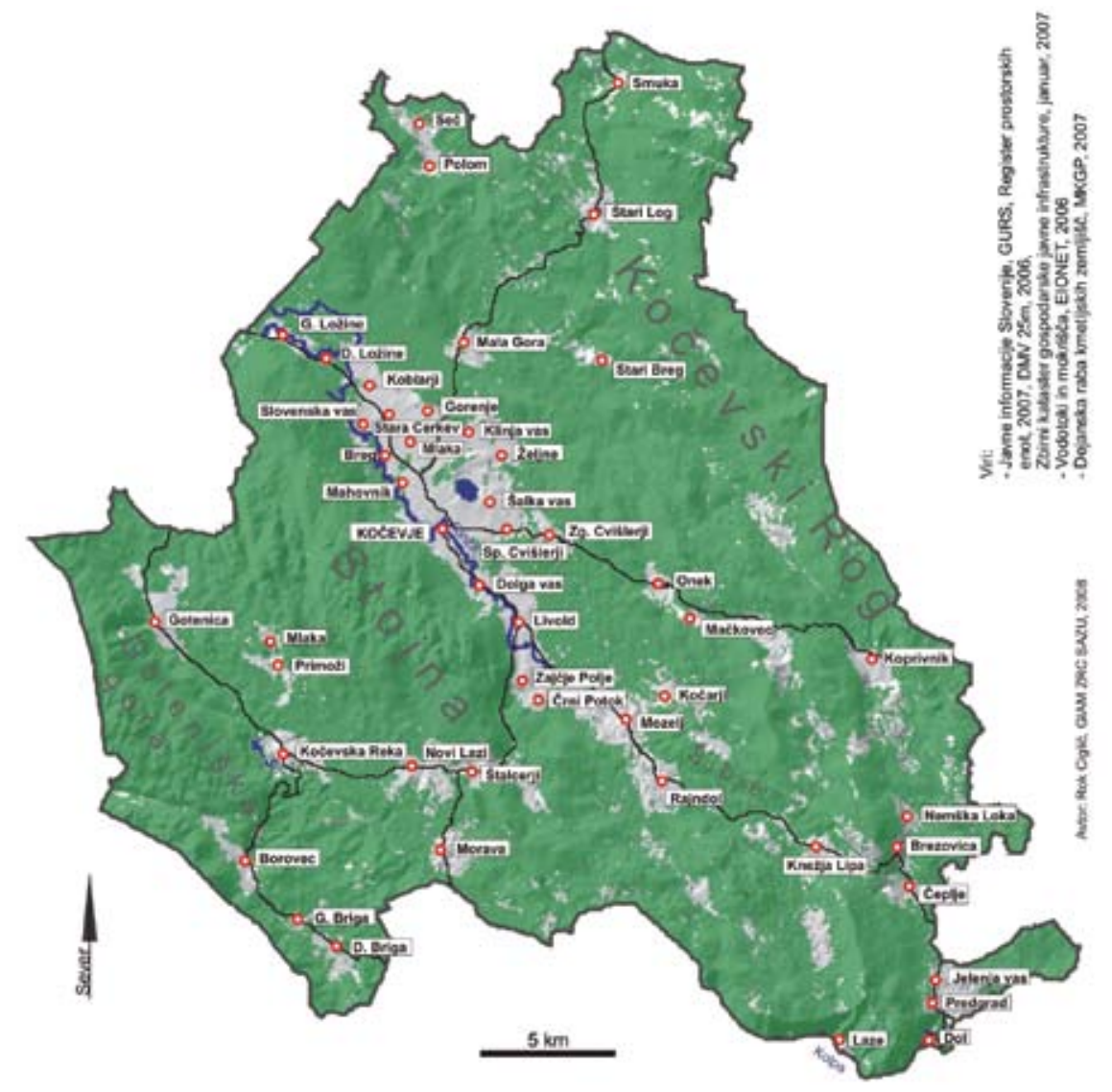

V našem primeru je bilo v analizo vključenih več dejavnikov (podatkovnih slojev), ki so navedeni v preglednici 1 . Na njihov izbor je vplivala dostopnost, natančnost in pomembnost podatkov. Vsi so bili pripravljeni kot rastrski podatkovni sloj z velikostjo celice $25 \times 25 \mathrm{~m}$ ter združeni po sklopih z opisanim GIS postopkom v programu Idrisi. Uteži pri združevanju podatkov so bile določene s pomočjo priporočil iz literature in so pripisane v oklepaju v preglednici 1. Sklopi so bili na drugi ravni med seboj združeni z enakimi utežmi $(0,33)$. 
Vrednotenje podatkov je potekalo s pomočjo spoznanj iz literature in zakonskih določil tako, da so bile dejanske vrednosti posameznega podatkovnega sloja prenesene na mersko lestvico primernosti z vrednostmi med 0 in 5. Podatkovni sloji, ki so označeni kot omejitev, so vsebovali le območja $\mathrm{z}$ vrednostjo 0 (za podroben opis vrednotenja glej Ciglič 2008). Zaradi računskega postopka $\mathrm{v}$ Idrisiju so bile vrednosti med 0 in 5 prenesene na razpon od 0 do 255; možna je tudi uporaba merske lestvice od 0 do 1.

Preglednica 1: V analizi uporabljeni podatkovni sloji

Table 1: Data layers used in analysis

\begin{tabular}{|l|l|l|}
\hline $\begin{array}{l}\text { 1. sklop - vrednotenje naravnih } \\
\text { dejavnikov }\end{array}$ & 2. sklop - vrednotenje rabe tal & $\begin{array}{l}\text { 3. sklop - vrednotenje zgrajene } \\
\text { infrastrukture }\end{array}$ \\
\hline $\begin{array}{l}\text { kamninska podlaga }(0,24) \\
\text { dna konkavnih oblik }\end{array}$ & $\begin{array}{l}\text { dejanska raba tal } \\
\text { naklon }(0,25)\end{array}$ & $\begin{array}{l}\text { cestno omrežje* }(0,33) \\
\text { elektroenergetsko omrežje* } \\
\text { odlagališč (omejitev) } \\
\text { osončenost }(0,03)\end{array}$ \\
$\begin{array}{l}\text { vodovarstveno območje }(0,27) \\
\text { vodno in poplavno območje } \\
\text { (omejitev) }\end{array}$ & $\begin{array}{l}\text { mineralnih surovin (omejitev) } \\
\text { vodovodno omrežje* }(0,33) \\
\text { varovalni gozd (omejitev) } \\
\text { gozd s posebnim pomeno omrežje* (omejitev } \\
\text { (omejitev) }\end{array}$ & \\
$\begin{array}{l}\text { varovalnega pasu) } \\
\text { kakovosti }(0,07)\end{array}$ & \\
tip vodonosnika $(0,12)$ & & \\
\hline
\end{tabular}

* Pri podatkovnih slojih smo upoštevali tudi infrastrukturne vode, ki so v neposredni bližini občine.

\subsection{Rezultati}

Na prvi ravni preučevanja je bil za vsak sklop izdelan po en podatkovni sloj, torej skupaj trije. Ti ločeno podajajo primernost za poselitev z vidika naravnogeografskih dejavnikov, obstoječe rabe tal ter zgrajene infrastrukture. Končna sintezna karta (na drugi ravni) pa podaja skupno oceno primernosti posamezne celice.

Ob pregledu grafikona (slika 3), ki ponazarja delež celic po primernosti za rezultate po posameznih sklopih in končni rezultat vidimo, da metoda ne podaja vrednosti (z izjemo omejitev, ki imajo vrednost 0 ) na celotnem razponu od 0 do 255 . Tako so vrednosti podatkovnega sloja primernosti z vidika naravnih dejavnikov znašale med 81 in 237 , vrednosti pri primernosti z vidika zgrajene infrastrukture med 139 in 255 ter vrednosti pri končnem rezultatu med 134 in 240. Pri vrednotenju obstoječe rabe tal je šlo za vrednotenje enega podatkovnega sloja z upoštevanjem nekaterih omejitev. Ker večino občine pokrivajo gozdne površine in ima zato večina celic v tem sloju (prek 90 \%) enako vrednost, v grafikonu to ni prikazano.

Odsotnost celic z nizko vrednostjo je posledica uporabljene računske metode in določenih uteži za posamezne naravne dejavnike. Izbrana metoda (WLC) namreč sešteva vrednosti posameznih podatkovnih slojev (Eastman 2001). Največjo težo pri naravnih dejavnikih 
so imeli vodovarstveno območje, naklon in kamninska podlaga. Ker ima predvladujoča kompaktna karbonatna kamninska podlaga dobro stabilnost in nosilnost (Gabrijelčič 1985) ter večina območja ni na vodovarstvenem območju, je večina celic dobila dokaj dobre ocene. Poleg tega digitalni model reliefa ublaži dejanske naklone in dodatno pripomore k boljšim rezultatom.

Slika 3: Relativna frekvenčna porazdelitev celic po primernosti za poselitev

Figure 3: Relative frequency distribution of cells by suitability for settlement

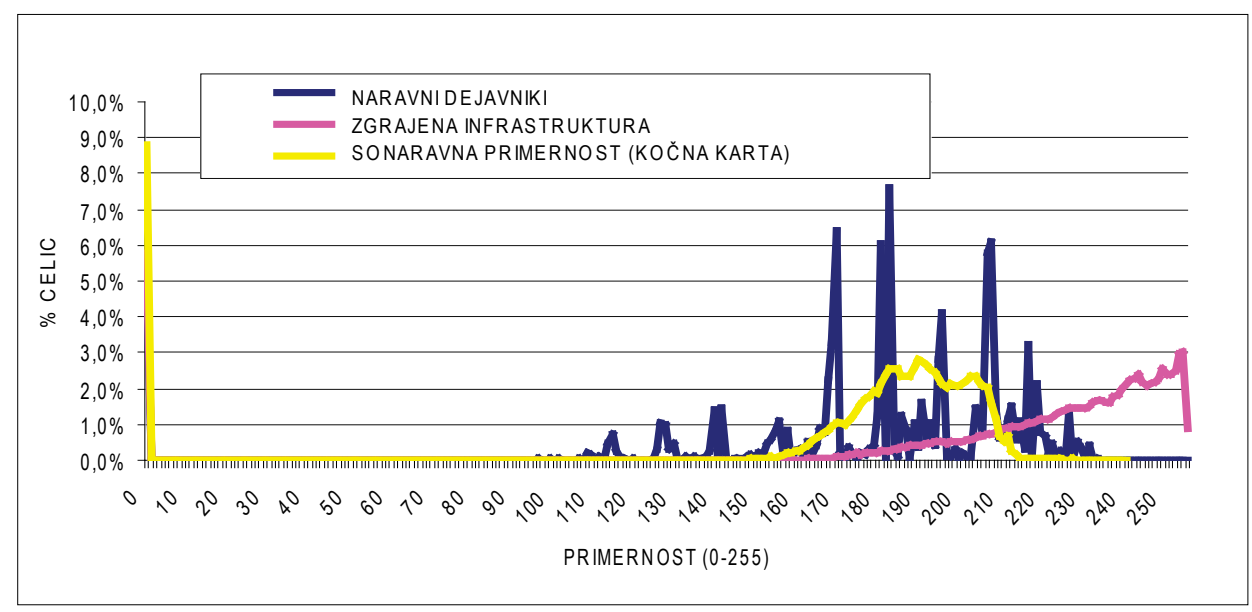

Vrednosti pri končni karti sonaravne primernosti za poselitev (brez že pozidanih površin in omejitev oziroma vrednosti 0) so razporejene normalno, kar smo preverili tudi s koeficientoma asimetrije in sploščenosti. Zaradi tega lahko primerne površine dobro prikažemo $\mathrm{s}$ pomočjo razredov, $\mathrm{v}$ katerih je enako število enot (celic). Pri tem prikazu sicer ne moremo ugotoviti, za koliko so določene celice bolj ali manj primerne od ostalih, lahko pa vseeno dobimo pogled na razlike v primernosti za širitev poselitve na območju celotne občine. Takšen pregled nam namreč prikazuje območja, ki so povsem neprimerna ali pa zelo malo primerna za poselitev in se jim moramo izogibati ter na drugi strani območja, ki so med najbolj primernimi za poselitev (slika 4).

Prikaz rezultatov je možen tudi na ta način, da izberemo $10 \mathrm{~km}^{2}$ najbolj primernih površin in ugotovimo, kje se nahajajo, kje je njihova največja gostota in kje so večja zaključena območja najbolj primernih površin za poselitev (slika 5). Trenutno zavzema pozidano območje vključno s cestami ravno $10 \mathrm{~km}^{2}$ občine (medmrežje 1). Torej bi morali v primeru podvojenih potreb po zazidljivih površinah (kar je sicer malo verjetno) nove površine iskati ravno med temi najprimernejšimi nepozidanimi površinami.

V splošnem lahko ugotovimo, da je koncentracija najboljših zemljišč za poselitev na Kočevskem polju ter izven njega ob naseljih Kočevska Reka, Morava, Štalcerji, Dolnja Briga, Seč, Polom, Stari Log, Smuka, Rajndol in Knežja Lipa. Območja se širijo ob prometnicah, kjer so pogosto tudi trase elektroenergetskih in vodovodnih vodov. To je še posebej opazno 
med Rajndolom in Brezovico (ob cesti Kočevje-Črnomelj). Nekatera območja, ki so bolj odmaknjena od središča občine Kočevje, bi lahko bila primerna tudi za gradnjo turistične infrastrukture (npr. počitniških hišic).

Slika 4: Primernost območja za poselitev v občini Kočevje

Figure 4: Suitability of the area for settlement in Kočevje municipality

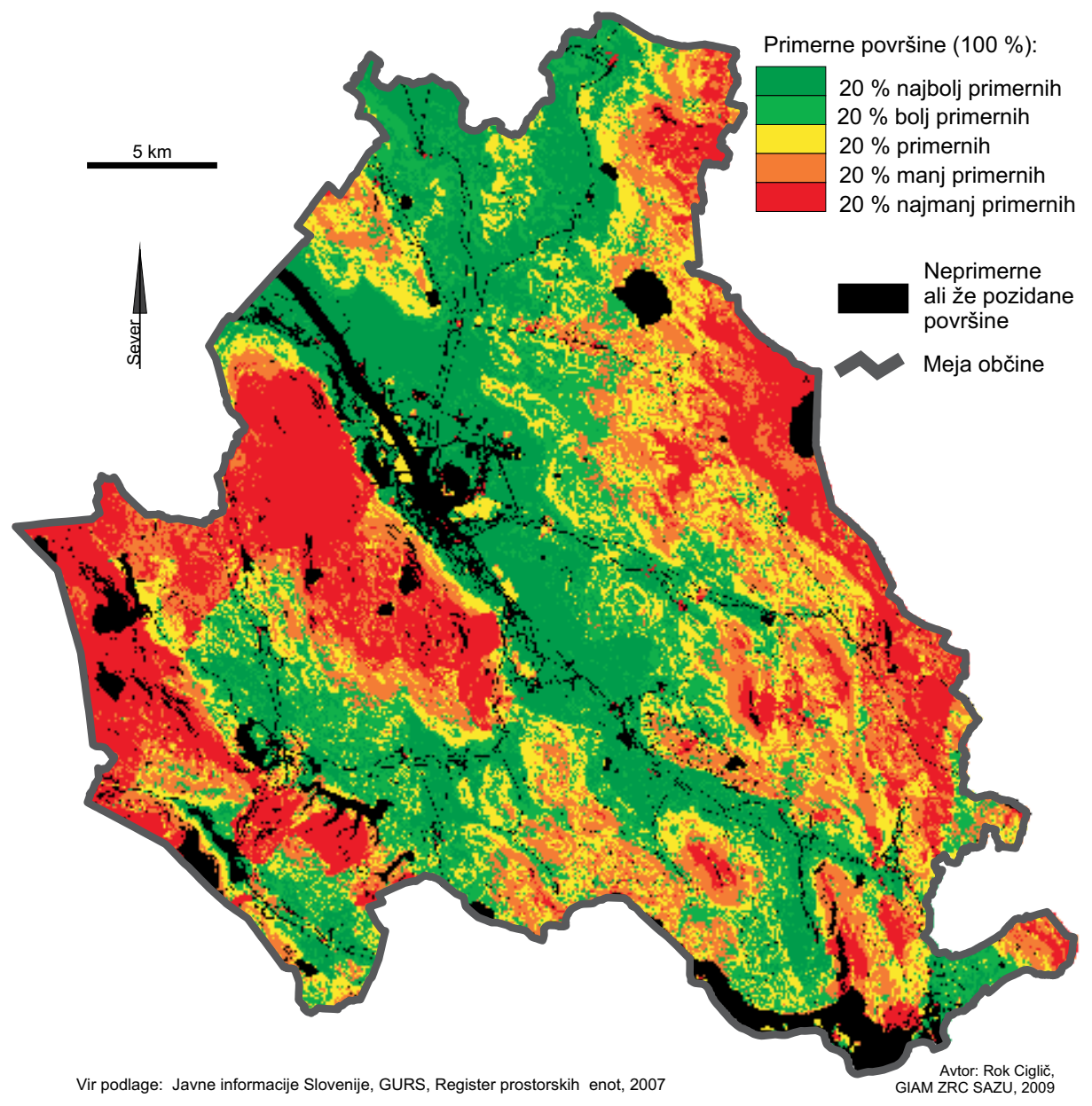


Slika 5: Najprimernejše neposeljene površine $\left(10 \mathrm{~km}^{2}\right)$ v občini Kočevje

Figure 5: The best uninhabited areas $\left(10 \mathrm{~km}^{2}\right)$ in Kočevje municipality

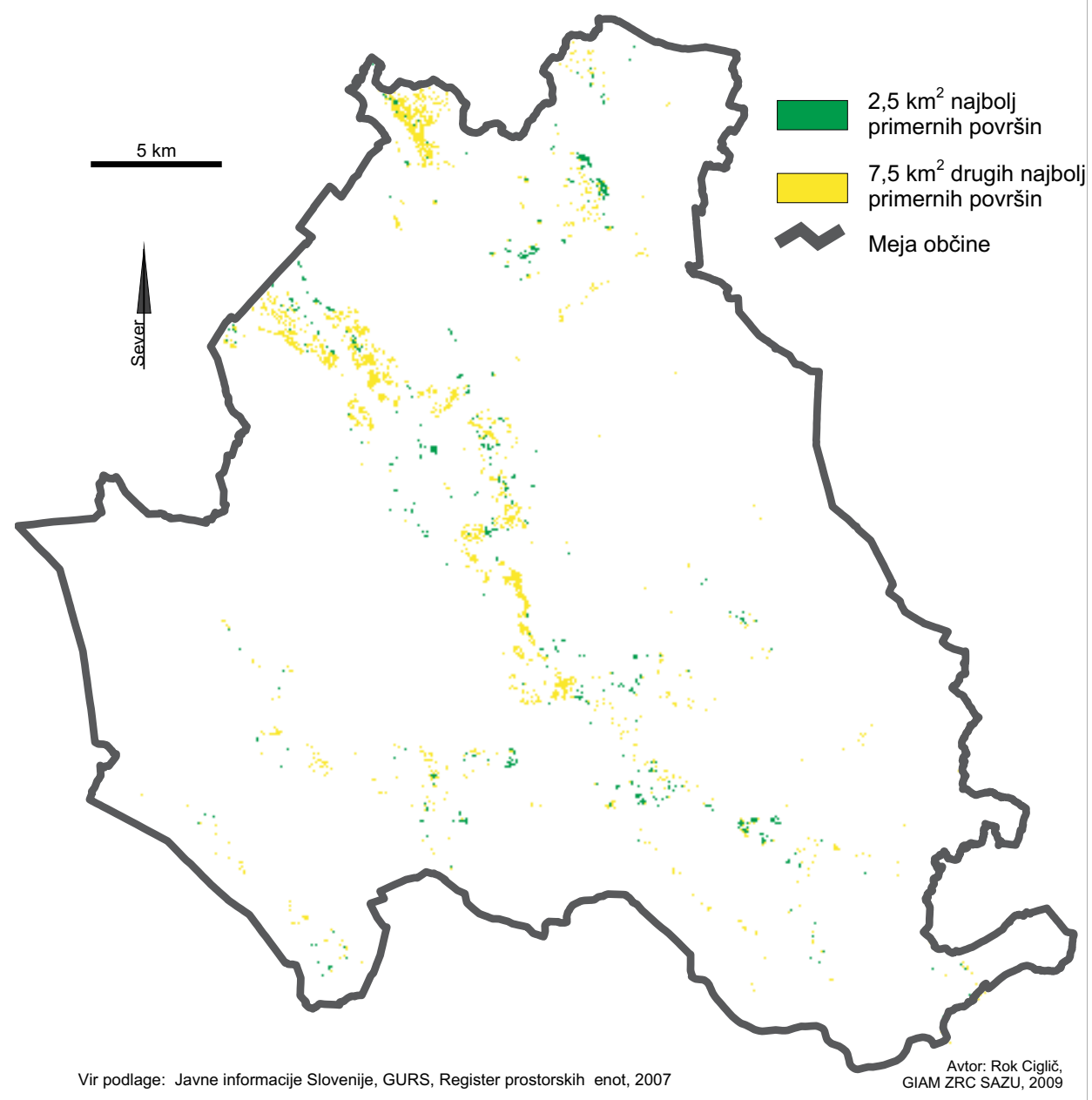

Opazno je pomanjkanje najbolj primernih površin v neposredni bližini Kočevja, kjer je sicer nekaj površin na vzhodnem in južnem robu mesta. Ovire predstavljajo strmo pobočje Stojne na zahodu, poplavna ravnica na severozahodu, jezero na severovzhodu ter naravni spomenik Željnske jame na vzhodu. V neposredni bližini mesta je tudi veliko kmetijskih površin. 
Omejitev z vidika naravnih dejavnikov je sicer v občini največ zaradi naklona in zaščitenih gozdov (varovalni gozdovi in gozdovi s posebnim pomenom), nekaj večjih območij z omejitvijo pa prispevajo še vodne in poplavne površine ter neprimerna kamninska podlaga. Najstrožjih vodovarstvenih območij in najstrožje zaščitenih varovanih območij naravnih kakovosti (naravni spomenik) je zelo malo - le $0,58 \mathrm{~km}^{2}$. Nekatera območja se ne sme poseliti zaradi načrtovane in trenutne namembnosti prostora, nekatera pa zaradi varovalnih pasov obstoječe infrastrukture. Skupna površina vseh omejitev obsega 7 \% vseh površin, skupaj z že pozidanim pa približno $9 \%$. Za najbolj primerna območja je značilno, da so v bližini že poseljenih površin in zgrajene infrastrukture, da ne zasedajo njivskih površin in površin sadovnjakov ter da so na uravnanih območjih (na najboljših $10 \mathrm{~km}^{2}$ površin je povprečni naklon $3^{\circ}$ ).

Zaradi navedenih dejstev nekdanja razpršena gradnja ni priporočljiva. Obnova naselij, ki so bila opuščena, bi v večini zahtevala velik vložek v izgradnjo osnovne infrastrukture. Tista opuščena naselja, ki z vidika naravnih dejavnikov izkazujejo večjo primernost (in so hkrati še v bližini zgrajene infrastrukture), bi lahko vseeno znova uredili; tudi kot turistično naselje. Kot tak primer navajamo opuščeno naselje Novi Log, ki se nahaja v bližini Starega Loga ob cesti Kočevje-Novo mesto.

Izmed bolj primernih območij bi se dejansko lahko poselilo le tiste dele, ki zavzemajo večje zaključene površine. Pri končnem umeščanju poselitve v prostor bi morali povečati pomen terenskega dela, saj so nekateri dostopni digitalni podatki premalo natančni za določanje primernosti na mikrolokacijski ravni. Kot primer lahko vzamemo poplavne površine, za katere so podani le bolj posplošeni podatki, saj niso zajeta dna vrtač in nekaterih najnižjih delov polja, ki so občasno poplavljeni (npr. okolica Zgornjih, Spodnjih in Novih Ložin). Poleg tega se moramo zavedati, da so nekatera območja sicer primerna s prostorskega vidika, a imajo v poletnih mesecih težave z vodooskrbo. Gre predvsem za območje na severovzhodu občine ter nekatera druga manjša naselja, kot sta npr. Borovec in Brezovica (Gašparac 2008). Zato je pred končnimi odločitvami obvezna tudi analiza možnosti oskrbe z vodo, energijo, daljinskim ogrevanjem in podobnim in ne samo prostorska analiza izbranih dejavnikov. Pri tem dodajamo, da za daljinsko ogrevanje nismo uspeli pridobiti podatkov. V nasprotnem primeru bi se površine okrog Kočevja in Kočevske Reke izkazale kot še bolj primerne.

\subsection{Odprta vprašanja}

Pomanjkljivost metode je subjektivnost, ki se ji pri vrednotenju dejavnikov in določanju uteži ne moremo izogniti, lahko pa jo zmanjšamo s sodelovanjem delovne skupine predstavnikov različnih strok. Seveda je uspeh odvisen tudi od priprave podatkov, še posebej, če je treba podatke digitalizirati in (ali) rasterizirati, saj to lahko pomembno vpliva na njihovo kakovost. Navsezadnje pa moramo biti tudi malce previdni in kritični do kakovosti samih podatkov (prostorska natančnost, doslednost pri izdelavi). Ravno zaradi tega si je treba pred konkretnimi odločitvami izbrana območja natančno ogledati.

Predstavljena metoda podaja primernost le za eno izmed dejavnosti (v našem primeru poselitev), lahko pa se uporabi tudi za druge (kmetijstvo, industrija, rekreacija, ...). Primerjava končnega rezultata za posamezne dejavnosti pokaže, kje prihaja do prekrivanj. Tovrstne 
težave lahko rešujemo prav tako $\mathrm{z}$ uporabo geografskih informacijskih sistemov z metodami za večciljno odločanje.

Navedena dejstva zahtevajo dodatne izboljšave na področju rabe GIS-ov in prostorskega planiranja nasploh. Ena od možnosti spremembe je uporaba dodatnih obtežitev najnižjih vrednosti za posamezno celico z metodo urejenega obteženega povprečja. Druga je ta, da se le za najboljše območje analiza ponovi in se upošteva bolj specifične dejavnike, brez tistih, ki se v tistem delu ne spreminjajo tako močno kot na celotnem območju (npr. občine).

\section{SKLEP}

Prostorsko planiranje dobiva z zmogljivimi računalniškimi tehnologijami in vse bolj natančnimi prostorskimi podatki podlago za dobro delo ter hkrati tudi večjo odgovornost, da bodo načrtovani posegi v okolje strokovno utemeljeni in okoljsko upravičeni. Za obvladovanje vse večjega pretoka informacij in čim bolj smotrno odločanje je treba razvijati tudi temu primerne metode. V tem prispevku smo v oblikovanje metode vrednotenja naravnih in družbenih dejavnikov za razvoj poselitve zato vključili takšno GIS metodo, ki omogoča obvladovanje velike količine prostorskih podatkov, torej lažje, a hkrati dovolj sistematično vrednotenje podatkov in prikaz rešitev.

Vrednotenje raznih podatkovnih slojev je mogoče razdeliti v vsaj dve ločeni skupini: vrednotenje naravnih dejavnikov in vrednotenje družbenih dejavnikov. Od namena analize je odvisno, kako bo le-ta potekala v podrobnem. Pri iskanju potencialnih površin za poselitev se je izkazalo, da je vrednotenje naravnih dejavnikov z vidika primernosti za poselitev ter regeneracijskih in nevtralizacijskih sposobnosti mogoče v enem sklopu. Vrednotenje ostalih (družbenih) podatkov pa je skoraj nujno v vsaj dveh ločenih sklopih. V našem primeru je bila najprej ovrednotena raba tal, pri čemer se je skušalo upoštevati trenutne pritiske posamezne rabe tal na okolje ter pomen rabe tal za gospodarstvo. V drugem sklopu se je vrednotila zgrajena infrastruktura, ki omogoča osnovne pogoje za razvoj naselij. Tu niso bili v ospredju pritiski na okolje, temveč razvitost komunalne opremljenosti (kot razvojni potencial).

V zadnjem koraku so vsi ti delni rezultati združeni in prikazani na eni karti, saj je tudi zemeljsko površje samo eno in kot tako zahteva enotno sintezno oceno, predvsem kadar gre za vrednotenje razvojnih možnosti določene dejavnosti (v našem primeru poselitve).

S predstavljeno metodo smo tako uspeli določila smernic prenesti v prostor na dokaj natančno enoto - celico z velikostjo $25 \times 25 \mathrm{~m}$.

Kot najbolj primerne potencialne poselitvene površine so se na obravnavanem območju pokazale predvsem na Kočevskem polju in ob nekaterih glavnih prometnicah, ob tem pa se je razkrilo pomanjkanje najbolj primernih površin v neposredni bližini mesta Kočevje. S prikazanimi rezultati so se nakazale razvojne možnosti in morebitni problemi prostorskega razvoja poselitve.

Metoda sicer ne more nadomestiti celotnega procesa odločanja o prihodnji namembnosti prostora, je pa lahko dopolnilo k raziskavam in lahko služi kot osnova za nadaljnje delo. Omogoča namreč dober vpogled na večje območje in prihrani čas in denar pri iskanju zaključenih območij za širitev posamezne dejavnosti, ki pridejo v izbor za podrobne terenske analize. 


\section{Viri in literatura}

Ciglič, R. 2008: Sonaravne smernice za prostorski razvoj poselitve v občini Kočevje.

Diplomsko delo, Oddelek za geografijo Filozofske fakultete Univerze v Ljubljani. Ljubljana.

Černe, A. 2002: Geografski pogledi na strokovne planerske analize. Dela 18. Ljubljana.

Eastman, R. J. 2001: Guide to GIS and image processing. Worcester.

Gabrijelčič, P. 1985: Varstvo in urejanje kulturne krajine. Magistrska naloga, Fakulteta za arhitekturo, gradbeništvo in geodezijo Univerze v Ljubljani. Ljubljana.

Gašparac, A. 2008: Vodovodno omrežje v občini Kočevje. Hydrovod Kočevje d.o.o. Kočevje (ustni vir).

Medmrežje 1: http://rkg.gov.si/GERK/Za_OB/ (23. 12. 2007)

Medmrežje 2: http://www.kocevje.si/zgodo.htm (10.10.2008)

Medmrežje 3: http://www.surs.si (10. 9. 2007)

Odlok o strategiji prostorskega razvoja Slovenije. Uradni list RS 2004/76. Ljubljana 2004.

Plut, D. 2002: Teoretični in terminološki vidiki koncepta trajnostnosti/sonaravnosti.

Geografski vestnik 74, 1. Ljubljana.

Plut, D. 2005: Teoretična in vsebinska zasnova trajnostno sonaravnega napredka. Dela 23.

Ljubljana.

Pogačnik, A. 1992: Urejanje prostora in varstvo okolja. Ljubljana.

Pogačnik, A. 1999: Urbanistično planiranje. Ljubljana.

Rejec Brancelj, I. 2001: Kmetijsko obremenjevanje okolja v Sloveniji. Ljubljana.

Strategija prostorskega razvoja Slovenije. Ljubljana 2004.

Špes, M., Cigale, D., Lampič, B., Natek, K., Plut, D. 2002: Študija ranljivosti okolja,

metodologija in aplikacija. Geographica Slovenica 35, 1-2. Ljubljana.

Vrišer, I. 1997: Metodologija ekonomske geografije. Ljubljana.

\section{EVALUATION OF NATURAL AND SOCIAL FACTORS FOR SUSTAINABLE DEVELOPMENT WITH THE HELP OF GEOGRAPHICAL INFORMATION SYSTEMS}

\section{Summary}

A common issue in spatial planning is where specific types of land use should be developed. Various natural and social factors differ within landscape. Their combinations produce different types of landscapes with their particular characteristics. Conversely, every activity (or land use) has its own development terms. This situation requires from the spatial planners to take into consideration the various natural and social factors and restrictions. Moreover, the Spatial development strategy of Slovenia (2004) emphasizes the importance of natural factors, current land use, and infrastructure.

Because of the large land area and many variables, an enormous amount of data must be analyzed. This means it is necessary to use geographic information systems. One of the 
possible options is software for multi-criteria evaluation. Boolean maps and weighted linear combination are two commonly used methods for such evaluation.

Data on natural and social specification are used in various methods, such as the environmental vulnerability study (Špes et al. 2002). This method served as a basic guide for developing the methodology used in this article. The method determines the suitability for development of a particular human activity. In the first stage, it is divided into three sections. The first-stage results are then combined in the second stage. In the first section (of first stage), natural factors are evaluated; in the second, current land use; and, in the third, the existing infrastructure. Social factors are divided into two sections because they may be understood as pressure on the environment or as important factors for a specific human activity.

In the case presented, data layers (constraints and factors) were combined with a weighted linear average (using Idrisi32 software). This method was used for determining areas of potential settlement in Kočevje municipality. The current settlement and population are concentrated in the Kočevje polje ( $90 \%$ of the population) and along the main roads in some larger villages (5\%). The rest of population (5\%) lives in other smaller settlements, and most of the municipality is uninhabited and covered with extensive fir and beech forests.

Various data were used for this analysis: bedrock, concave relief structures, slope, solar radiation, water protection areas, water and flood areas, protected forest areas (two types), other protected areas (four types), current land use, dumping grounds, quarries, the road system, the electricity network, waterworks, and the railway system.

Three data layers were produced for each section in the first stage: suitability for settlement defined by natural factors, suitability for settlement defined by land use, and suitability for settlement defined by existing infrastructure. The results, calculated from these three data layers, offer information about the general suitability for potential settlement of uninhabited areas. The best areas are those near current settlements and situated on flat land away from orchards and fields.

The best areas are on the Kočevje polje and along major roads. The lack of high potential areas around Kočevje, with only a few suitable areas to the east and south, is clearly seen. This is because of the presence of steep hillsides to the west, flood areas to the northeast, an artificial lake to the north, a protected area to the east and some farmland all around. However, all constraints together occupy only $7 \%$ of the municipality. Build up areas occupy $2 \%$.

The settlement system should not be expanded. Renovation of villages abandoned during the Second World War is possible only where there is adequate infrastructure (usually near major roads) and where natural factors allow resettlement. Remote abandoned villages with high natural suitability for settlement could be used as small tourist centers.

The results of the method presented here show development suitability for only one human activity: settlement. The method could be also used to define potential areas for other activities (e.g., farming, industry, recreation, etc.). One drawback of the method is its subjectivity. Researchers must take care when gathering various types of data because the analysis results depend on the quality of the input data. 